\title{
Genetic Aspects of Autism Spectrum Disorders: From Bench to Bedside
}

\author{
Ivanka Dimova and Draga Toncheva \\ National Human Genome Center, \\ Department of Medical Genetics, Medical University of Sofia, \\ Bulgaria
}

\section{Introduction}

Autism is a complex disorder of the immature brain, caused by different genetic and nongenetic factors and characterized by a certain behavioral phenotype. Autistic spectrum disorders (ASD) may be isolated or syndrome, in the latter case combined with other clinical symptoms, facial dysmorphism, abnormalities of the limbs or internal organs, growth retardation.

According to DSM-IV (Diagnostic and Statistical Manual of Mental Disorders) and ICD-10 (International Classification of Diseases) autism includes symptoms of varying degrees in three categories: social interaction, communication, stereotyped behaviors. Leo Kanner defines two most typical early childhood autism disorder: 1 . extreme loneliness (inability to establish normal contacts even with the closest) and 2. striving for permanence (any change in the surrounding world is of concern; sick child requires ritual immutability even in actions related to its service).

DSM-IV defines five subtypes of Pervasive Developmental Disorders (PDD):

- Classic autism

- Asperger Syndrome (develop speech in the expected age, normal mental development);

- Desintegrative disorder (Heller syndrome)

- Regression in cognitive abilities, motor skills and communication between 2 and 10 years of age, after a period of "normal" development in the first few years;

- Autistic behavior, not otherwise specified (individuals with autistic behavior not consistent with other subtypes);

- $\quad$ Rett Syndrome

The incidence of autism is 3-6/1000, the ratio men: women is $4: 1$. In recent years, the frequency of patients with autism is increasing. This is due to greater awareness of medical professionals and changing diagnostic criteria, inclusion of patients with attention deficit and hyperactive behavior in this group, rather than a real increase in incidence of autism. Clinical picture comprises lack of interest in the environment, lack of eye contact, lack of subject matter, motor and verbal stereotypes; agramatism (speak for yourself in the third person) with a peculiar intonation, singing, not asking questions. Sometimes the children develop strange passions (in numbers, equipment, etc.). 
The diagnosis of "autism" is often difficult due to high variability of symptoms in different individuals and in the same patient over time. Today it is considered that $11-37 \%$ of cases of autism are within a syndrome that can be diagnosed by specific laboratory markers and / or its characteristic phenotype, chromosomal aberrations, single gene diseases (tuberous sclerosis, fragile $\mathrm{X}$ syndrome chromosome), environmental factors.

Despite of the organic basis of this disease, today it is diagnosed based on criteria established by consensus and not by biological markers. Family studies and those among twins show higher concordance in monozygous (60-91\%) than in dizygous twins (0-6\%). These studies support the existence of a genetic component in the etiology of autism. Autism is an example of high genetic heterogeneity.

\section{Chromosomal aberrations in autism}

Chromosome abnormalities have long been recognized as an important cause of learning disabilities and multiple malformation syndromes. About $0.8 \%$ of live born infants have numerical or structural chromosomal anomalies that result in an abnormal phenotype. Identification of such anomalies is important clinically and also for accurate genetic counseling. Recently, molecular-cytogenetic and array-based techniques have enabled higher resolution screens for chromosome anomalies. Since all patients with a chromosomal imbalance are dysmorphic, the association of ASD with a facial dysmorphism seems to be a good indication for chromosomal anomaly screening. Clinical features that predict an increased likelihood of finding a cytogenetic abnormality on routine testing include: congenital delay in neuro-cognitive development, one or more major malformations, prenatal onset abnormal growth pattern, craniofacial dysmorphism, unusual behavioral phenotypes, often in the autistic spectrum, and a family history of multiple miscarriages, learning disabilities or malformations. High resolution chromosome banding has been reported to have an overall detection rate of $7.5 \%$ for anomalies in patients with mental retardation/learning disabilities. It is recently reported that de novo balanced chromosomal rearrangements have high risk of neurodevelopmental and psychiatric disorders. Conventional cytogenetic analysis uses light microscopy to examine metaphase or prometaphase chromosomes that have been stained to produce a distinct banding pattern for each chromosome. This approach has a maximum resolution of 3-5 $\mathrm{Mb}$ for structural anomalies and requires mitotic cells, usually peripheral blood leucocytes, bone marrow, or fibroblasts, for analysis.

About $5 \%$ of individuals with an ASD have a microscopically identified chromosomal alteration. Cytogenetic assays have long been used to uncover chromosomal defects in patients with autism. Almost all chromosomes have been involved. The incidence of de novo chromosomal aberrations may be increased in groups of persons with autism, suggesting a causal relationship between certain chromosomal aberrations and the occurrence of isolated idiopathic autism.

By conventional cytogenetic and fluorescent in situ hybridization (FISH) methods a number of chromosomal abnormalities were found in 1.7 to $4.8 \%$ of patients with autism. The most frequent aberrations were abnormalities of 15q11-q13 locus (duplications, deletions and insertion - in $1-4 \%$ of cases), deletions of $22 q$ and $16 p$, as well as partial monosomy $X$. Some of cytogenetic anomalies in autistic patients are presented in table 1. 


\begin{tabular}{|c|c|}
\hline Chromosomal aberration & References \\
\hline $\operatorname{inv}(3)(p 14 ; q 21)$ & de Silva et al. (2003) \\
\hline 7q11.23 duplication (locus of Williams) & $\begin{array}{l}\text { Somerville et al. (2005) } \\
\text { Depienne et al. (2007) }\end{array}$ \\
\hline $7 q$ inversion & Arking et al. (2008) \\
\hline 13q14-q22 deletion & Steele et al. (2001) \\
\hline 15q11-q13 duplication & Cook et al. (1997) \\
\hline $15 q 11.2$ isodicentric chromosome & Wolpert et al. (2000) \\
\hline 15q25.2-qter trisomy & Bonati et al. (2005) \\
\hline $\begin{array}{l}\text { 16p11.2 deletion } \\
\text { 16p11.2 duplication }\end{array}$ & $\begin{array}{l}\text { Shinawi et al. (2010) } \\
\text { Sebat et al. (2007) } \\
\text { Bijlsma et al. (2009) } \\
\end{array}$ \\
\hline genomic instability at $16 \mathrm{p} 11.2$ & Eichler and Zimmerman (2008) \\
\hline $\mathrm{t}(13 ; 17)(\mathrm{q} 14 ; \mathrm{p} 13)$ & Tentler et al. (2002) \\
\hline 22q13 telomeric deletion & $\begin{array}{l}\text { Luciani et al. (2003) } \\
\text { Lindquist et al. (2005) } \\
\text { Wilson et al. (2003) } \\
\end{array}$ \\
\hline 22q13 interstitial deletion & Wilson et al. (2008) \\
\hline Xp22.11 deletion & $\begin{array}{l}\text { Marshall et al. (2008) } \\
\text { Filges et al. (2011) }\end{array}$ \\
\hline
\end{tabular}

Table 1. Frequent chromosomal aberrations in patients with ASD

\section{Autism in syndromes}

- Fragile X chromosome Syndrome

Fragile X chromosome Syndrome (FXS) is characterized by facial dysmorphism (long face, large protruding ear mussel), large testis and various degrees of mental deficiency. This is the most common cause of inherited mental impairment, affecting 1 / 4000 males and 1 / 8000 women. It is caused by a dynamic mutation (variable number of CGG repeat) in FMR1 gene, located on the long arm of chromosome X (Xq27.3). FMR1 gene encodes a protein (FMRP) involved in the transport of RNA molecules from cell nucleus to cytoplasm.

About $90 \%$ of men with FXS have behavioral disorders that can be interpreted as abnormal social behavior, or behavior characteristic of autism spectrum - limb automatisms, avoiding eye contact, signs of auto-aggression. Approximately 30\% of individuals with FXS have autism.

- Prader-Willi/Angelman Syndrome

Angelman Syndrome (AS) and Prader-Willi Syndrome (PWS) are most often result of a deletion of 15q11-q13 locus. Abnormal imprinting or mutations are found in $\sim 5 \%$ of patients with PWS and 15\% of patients with AS. The loss of the father's genes in this locus leads to expression of PWS, loss or mutation of the maternal UBE3A or ATP10C gene causes AS.

AS is more often associated with autism than PWS. The diagnosis of AS should be suspected in patients with autism, severe mental deficiency and epilepsy. Between AS and autism, there is a number of common characteristics - a lack of expressive speech 
automatisms, attention deficit, hyperactivity, problems with sleeping and nutrition, and delayed motor development. It is known that duplication of maternal genes in the critical locus for AS is often associated with autistic symptoms. Majority of patients with Angelman syndrome $(42 \%-61 \%)$ meet the criteria for autism. In $25 \%$ of patients with Prader-Willi syndrome the autism diagnosis is inserted. The fact that autism occurs more often in maternal duplication of 15q11-q13 locus than in the forms with the deletion should be considered.

\section{- $\quad$ Turner Syndrome}

Turner Syndrome (TS) is caused by complete or partial absence of one $\mathrm{X}$ chromosome, it occurs with an incidence 1:2500 girls. Characteristics of the syndrome is the presence of gonadal dysgenesis, infertility, short stature, short neck with pterigium, facial dysmorfism, coarctation of the aorta, renal anomalies. Patients with TS have normal intelligence. Often they have reduced non-verbal skills and arithmetic skills with in a well-developed verbal intelligence. Haploinsufficiency of one or more genes in Xp22.3 region determine typical TS neurocognitive phenotype. There is an increased risk of autism in these children as $5 \%$ have classic autism, and $>25 \%$ are with autistic spectrum disorders. Girls with TS inheriting X chromosome from their mothers have poorer social skills than those inheriting $X$ chromosome from their fathers and they are more often with autism. It is believed that on the $\mathrm{X}$ chromosome exist a gene determining social skills, which is expressed only when this chromosome is inherited from the father.

\section{Autism with known single gene defect}

\section{- Rett syndrome}

Rett Syndrome (RS) is the only autistic spectrum disorder with a known etiology, which affects 1:12500 women (Figure 1). It is X-linked syndrome, a consequence of mutation in MECP2 gene (Xq28), encoding methyl-CpG-binding protein-2, MECP2. Atypical forms of the syndrome, with early onset epilepsy or cramps, may be due to mutation in gene for cyclin-dependent kinase-like 5 (CDKL5).

Like the classic signs of autism, first clinical presentation of RS is between 6 and 18 months after the period of normal development. Clinical manifestations of the syndrome include regress in the neuro-psychological development, seizures, cognitive impairment, microcephaly, stereotype movements, abnormal socialization.

Many genetic and environmental factors can alter the level of MECP2 protein in the brain and cause an effect similar to mutation in $M E C P 2$ gene. Study the role of MECP2 in the pathogenesis of RS and autistic spectrum disorders are considered as "Rosetta Stone" that can be used in deciphering the complex etiology of autism.

- $\quad$ Tuberous sclerosis

Tuberous sclerosis (TSC) is an autosomal dominant neurodermatosis, due to mutations in TSC1 (9q34), which encodes the protein hamartin, or mutations in TSC2 (16r13.3) gene for the protein tuberin. Both proteins co-operate and participate in the control of cell growth and proliferation. Carriers of mutations in these loci are prone to tumor formation, skin changes and hamartoma in various organs (Figure 2). Brain lesions (tuberosis) lead to epilepsy in more than $3 / 4$ of patients with TSC. 
Given the high incidence of epilepsy in children with TSC and the frequent association between epilepsy and autism, it is not surprising that approximately $25 \%$ of patients with TSC are autistic. Among patients with autism, the incidence of TSC is 1.1 to $1.3 \%$, this percentage is by $30 \%$ higher than the incidence of TSC in the general population.

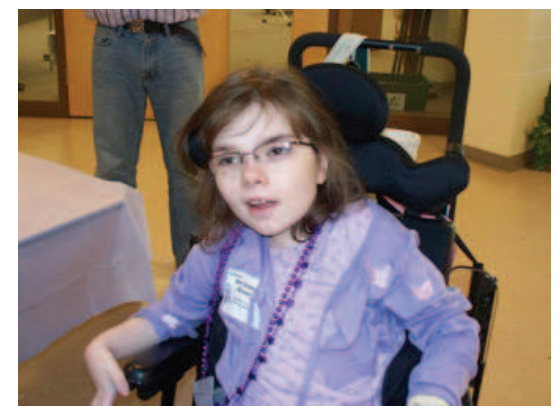

Fig. 1. Rett Syndrome (www.canajoharieschools.org)

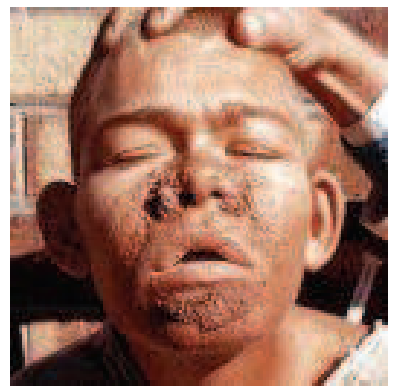

Fig. 2. Tuberous sclerosis (www.benmoonpharma.com)

\section{- Neurofibromatosis type 1}

Neurofibromatosis (NF1) is an autosomal dominant disease characterized by the development of multiple benign tumors of nerves and skin (nevrofibromas) and abnormal skin pigmentation (spots cafe-au-lait). Pigment patches are available at birth tended to increase in number and size over time. NF1 gene (17q11.2) encodes a protein called neurofibromin that functions as a tumor-suppressor. The incidence of NF1 in autistic people in different studies varies from 0.2 to $14 \%$. Patients with NF1 have a 100-190 fold higher risk of developing autism than in the general population. Sixfold repeat of the AAAT Alu sequences in the NF1 gene is found only in patients with severe autism, and not in controls groups.

- Metabolic diseases

Among patients with phenylketonuria, hyper-succinyl-purinaemia, lactic acidosis, abnormal metabolism of aromatic amino acids and cholesterol, autism is more common than in the general population. Selective metabolic screening is indicated in patients with autistic behaviors and symptoms characteristic of metabolic diseases, lethargy, cyclic vomiting, seizures, mental deficiency. In some patients the early diagnosis of metabolic disorder and appropriate treatment can significantly improve their cognitive and behavioral phenotype. 
In untreated patients with phenylketonuria it is very common the manifestation of autoaggression, hyperactivity, autism. It was found that $5.71 \%$ of patients diagnosed late with pathologic metabolic condition meet criteria for autism.

- Mitochondrial diseases

Proportion of patients with autism have an increased lactate. It is assumed that hyperlactate-acidaemia is a consequence of impaired oxidative phosphorylation process in mitochondria of neurons. The relationship between autism and mitochondrial diseases has been demonstrated and established by decreased activity of enzymes involved in oxidative phosphorylation, changes in the structure of mitochondria and various mutations in mitochondrial DNA. In 7.2\% of patients studied with autism mitochondrial disease has been proven. Mitochondrial disease as a cause of autism should be suspected in patients in which there is combination of epilepsy and signs of neurological and / or systemic dysfunction.

- $\quad$ Other single gene diseases

Elevated levels of uric acid is found in $1 / 4$ of the patients studied with autism. The reasons for this "purine autism" remain unclear. Autism is described in association with muscular dystrophy Duchenne, Sanfilippo syndrome, Sotos, Cowden, Moebius diseases.

\section{Genetic predisposition to autism}

Identification of genes participating in the development of a disease is of paramount importance for precise diagnostics and adequate effective treatment. That is why genetic investigations are wide spread in elucidating the etiology of the disease - linkage analysis for searching of candidate-genes, association analysis of biological candidate-genes, whole genome screening.

\section{- $\quad$ SNP associations in autism}

The human genome is huge, consisting of thousands genes. This is the reason why the discovering of specific gene/genes responsible for a disease is so difficult task. Gene mapping aims in establishing the location of genes related to specific disease by using other genetic markers (Single Nucleotide Polymorphisms - SNPs) with known localization. The genes or loci, which are objects of the mapping, are these ones, which are supposed to predispose to the disease of interest - they are called disease loci. In general, there are two approaches in accomplishing the goal of mapping: linkage analysis (Linkage mapping), that is used in large families, and association studies (Linkage disequilibrium mapping) at the level of population. In linkage analysis, it is not necessary to know the pathophysiology of the disease - they detect genes with considerable effect at large distances. In contrast, association studies discover genes with little effect at small distances, as it is necessary to know the biology of the studied disease. These two approaches very often are combined in the practice.

Single Nucleotide Polymorphisms (SNPs) represent changes in single nucleotides in DNA and occur with frequency $>1 \%$. Because of its extremely high density in the human genome, SNPs are ideal polymorphic markers for association studies in complex diseases. So far in the official database dbSNP (http://www.ncbi.nlm.nih.gov/SNP/, Genome build 36.3, dbSNP build 130) more than 10 millions SNPs are discovered and deposed. 


\begin{tabular}{|c|c|c|c|c|}
\hline Chr & Cytoband & Study & Candidate-genes & References \\
\hline 1 & 1q41-42 & $\begin{array}{l}62 \text { families with at least } 2 \\
\text { individuals had autism or } \\
\text { an autism spectrum } \\
\text { disorder }\end{array}$ & MARK1 & $\begin{array}{l}\text { Buxbaum et al. (2004) } \\
\text { Maussion et al., 2008). } \\
\text { Bartlett et al. (2005) }\end{array}$ \\
\hline 2 & $2 q 31-32$ & \begin{tabular}{|l|}
411 pedigrees including \\
671 autistic children; 158 \\
Irish child-parent rios ( 442 \\
individuals)
\end{tabular} & $\begin{array}{l}\text { cAMP-GEFII } \\
\text { (RAPGEF4), DLX1 } \\
\text { DLX2 }\end{array}$ & $\begin{array}{l}\text { Bacchelli et al. (2003) } \\
\text { Ramoz et al. (2004) } \\
\text { Segurado et al. (2005) } \\
\text { Liu et al. (2009) } \\
\text { Newbury et al. (2009) }\end{array}$ \\
\hline 3 & $3 q 24$ & $\begin{array}{l}38 \text { Finnish families in } \\
\text { which a proband had } \\
\text { autism; } 18 \text { families with } \\
\text { autism }\end{array}$ & $\begin{array}{l}\text { SLC9A9(R423X) } \\
\text { C3ORF58 (DIA1, } \\
\text { 'deleted in autism- } \\
\text { 1') }\end{array}$ & $\begin{array}{l}\text { Morrow et al. (2008) } \\
\text { Auranen et al. (2002) }\end{array}$ \\
\hline 4 & 4 p12 & \begin{tabular}{|l|}
470 white families with \\
autism ; 557 non-Hispanic \\
Caucasian families with \\
autism; 54 African \\
American families with \\
autism
\end{tabular} & GABRA4 GABRB1 & $\begin{array}{l}\text { Ma et al. (2005) } \\
\text { Collins et al. (2006) }\end{array}$ \\
\hline 5 & $5 p 14$ & \begin{tabular}{|l|}
780 families ( 3,101 \\
subjects) with affected \\
children; 1,204 affected \\
and 6,491 control subjects; \\
438 Caucasian families \\
with 1,390 individuals \\
with autism
\end{tabular} & $\begin{array}{l}\text { CDH9 } \\
\text { CDH10 }\end{array}$ & $\begin{array}{l}\text { Wang et al. (2009) } \\
\text { Ma et al. (2009) }\end{array}$ \\
\hline \multirow[t]{2}{*}{7} & $7 q 31$ & $\begin{array}{l}219 \text { affected sib pairs with } \\
\text { autism; } 204 \text { families with } \\
\text { autism; } 539 \text { additional } \\
\text { autistic families }\end{array}$ & $\begin{array}{l}\text { RAY1 (ST7) } \\
\text { MET } \\
\text { WNT2 }\end{array}$ & $\begin{array}{l}\text { Vincent et al. (2000) } \\
\text { Lamb et al. (2005) } \\
\text { Folstein and Mankoski } \\
(2000) \\
\text { Campbell et al. (2006) } \\
\text { Wassink et al. (2001) }\end{array}$ \\
\hline & $7 q 35-36$ & $\begin{array}{l}152 \text { families segregating } \\
\text { autism; } 635 \text { patients and } \\
942 \text { controls; } 539 \\
\text { additional autistic families }\end{array}$ & $\begin{array}{l}\text { CNTNAP2 } \\
\text { EN2 } \\
\text { FOXP2 CNTNAP2 }\end{array}$ & $\begin{array}{l}\text { Vernes et al. (2008) } \\
\text { Alarcon et al. (2008), } \\
\text { Arking et al. (2008), } \\
\text { Bakkaloglu et al.(2008) } \\
\text { Molloy et al. (2005) } \\
\text { Benayed et al. (2005) } \\
\text { Gharani et al. (2004) } \\
\end{array}$ \\
\hline 12 & 12q14 & $\begin{array}{l}26 \text { families with autism, } \\
\text { comprising } 65 \text { affected } \\
\text { individuals }\end{array}$ & & Ma et al. (2007) \\
\hline
\end{tabular}

Table 2. Mapping for predisposing genes in ASD 


\begin{tabular}{|c|c|c|c|c|}
\hline Chr & Cytoband & Study & Candidate-genes & References \\
\hline 15 & 15q11-13 & 221 patients with autism & GABRB3 & $\begin{array}{l}\text { Shao et al. (2003) } \\
\text { Tochigi et al. (2007) }\end{array}$ \\
\hline 16 & $16 \mathrm{p} 11$ & $\begin{array}{l}859 \text { patients of European } \\
\text { ancestry with autism } \\
\text { spectrum disorder and } \\
1,409 \text { controls }\end{array}$ & & Glessner et al. (2009) \\
\hline \multirow[t]{2}{*}{17} & 17q11 & $\begin{array}{l}117 \text { autistic trios; } 115 \text { trios } \\
\text { consisting of a proband } \\
\text { with autism and both } \\
\text { parents; } 84 \text { Irish families } \\
\text { with autism; } 384 \text { families } \\
\text { in which at least } 1 \text { child } \\
\text { had autism and a second } \\
\text { sib had autism or ASD }\end{array}$ & $\begin{array}{l}\text { 5-HTTLPR } \\
\text { SLC6A4 } \\
\text { 5-HTT }\end{array}$ & $\begin{array}{l}\text { Abramson et al., 1989; } \\
\text { Piven et al., 1991, } \\
\text { Klauck et al. (1997) } \\
\text { Kim et al. (2002) } \\
\text { Conroy et al. (2004) }\end{array}$ \\
\hline & 17q21 & $\begin{array}{l}56 \text { sib pairs from } 48 \\
\text { families with only } \\
\text { affected males; } 730 \\
\text { affected families; } 281 \\
\text { simplex and } 12 \text { multiplex } \\
\text { Caucasian families with } \\
\text { autism }\end{array}$ & ITGB3 & $\begin{array}{l}\text { Cantor et al. (2005) } \\
\text { Weiss et al. (2006) } \\
\text { Napolioni et al. (2011) }\end{array}$ \\
\hline 19 & 19p13 & $\begin{array}{l}20 \text { Finnish families with } \\
\text { autism }\end{array}$ & \begin{tabular}{|l|} 
TLE2 \\
TLE6
\end{tabular} & Kilpinen et al. (2009) \\
\hline 21 & 21p13-q11 & $\begin{array}{l}34 \text { families in which } 1 \\
\text { individual had autism, a } \\
\text { relative had either autism } \\
\text { or ASD, and both had a } \\
\text { definite history of } \\
\text { developmental regression }\end{array}$ & & Molloy et al. (2005) \\
\hline \multirow[t]{2}{*}{$X$} & Xp11 & 119 boys with autism & MAOA & Cohen et al. (2011) \\
\hline & $\mathrm{Xq28}$ & $\begin{array}{l}141 \text { individuals with } \\
\text { ASD; } 176 \text { ASD patients; } \\
38 \text { Finnish families; } 69 \\
\text { females with autism }\end{array}$ & $\begin{array}{l}\text { RPL10 } \\
\text { H213Q } \\
\text { MECP2 }\end{array}$ & $\begin{array}{l}\text { Gong et al. (2009) } \\
\text { Chiocchetti et al. } \\
\text { (2011) Auranen et al. } \\
\text { (2002) } \\
\text { Carney et al. (2003) }\end{array}$ \\
\hline
\end{tabular}

Table 2. Mapping for predisposing genes in ASD. (Continuation) 
By the abovementioned methods of analysis several regions are localized as associated with autism in 20 different chromosomes. Most of them are summarized in table 2. Some of the identified loci or polymorphisms showed association with specific clinical features of the autism. For example, linkage at 1q41-42 correlated to obsessive-compulsive behaviors; linkage to 2q31-32 - mild developmental delay particularly affecting speech and language, pervasive developmental disorder, attention deficit, obsessive traits, and bipolar disorder; 3q24 - Asperger syndrome or developmental dysphagia; 7q31 - specific language impairment; 7q35-36 - loss of language skills and/or loss of other socially communicative skills; Xp11 - more severe sensory behaviors, arousal regulation problems, aggression, and worse social communication skills.

In whole-genome scan of 10000 patients with ASD, members of their families and volunteers genetic variants associated with disease have been found. They are related to CDH9 and CDH10 genes that encode cadherins. Cadherins are proteins located on the surface of cells that are pivotal for cellular interactions. Other 30 genes for cell adhesion proteins (including other cadherins and neurexins) were also found to be strongly associated with autism. A positive association of autistic male with CNTNAP2 gene for neurexin was revealed. In the brain of fetuses, cell adhesion proteins allow neurons to migrate to the right places and connect with other neurons. Additionaly, it was found connection with rare variations in genes for the ubiquitin-proteasome system that may be included in the exchange of adhesion proteins on the cell surface. These results highlight the role of variations in genes coding proteins for intercellular adhesions to create a susceptibility to ASD.

One of the strongest candidate-gene for ASD, selected from association studies, is EN2, mapped to 7q36. EN2 mouse mutants display anatomic phenotypes in the cerebellum that are similar to those reported for individuals with autism. Population-attributable risk calculations for the associated haplotype, performed by using large sample of 518 families, determined that the risk allele contributes to as many as $40 \%$ of ASD cases.

\section{- $\quad$ Copy number variations $(\mathrm{CNV})$ in autism}

Literature data have showed that more than half of the variability between human genomes is due to submicroscopic copy number variations of DNA (microdeletions and microduplications), and that these CNVs are responsible for some complex diseases, even more than single nucleotide polymorphisms (Freeman et al., 2006; McCarroll and Altshuler, 2007; Redon et al., 2006). There are currently more than 6,000 known regions of CNV, and there are likely many more (Carter, 2007; Redon et al., 2006). Microarray-based Comparative Genomic Hybridization (array CGH) is currently one major technique for analyzing CNVs in a given individual (Carter, 2007). Array CGH is a sensitive, specific and rapid method for detecting unbalanced genomic changes. This method is used to detect submicroscopic aberrations, identifying critical DNA areas for a disease and clarify the genotype-phenotype correlation. Array CGH provides with direct link to genome database and potential candidate-genes, predisposing to the disease, could be revealed.

Emerged as a new molecular-genetic technique, array CGH is now used for screening the genome of affected individuals and their families and for the localization of specific genes or 
chromosomal regions potentially linked to autism. Using array CGH in patients with autism, unbalanced genomic changes were found in $10-27.5 \%$ of the affected individuals. The combination of facial dysmorphism with autism is an indication for conducting screening for chromosomal reorganizations.

Using high-resolution microarray analysis, Marshall et al. (2008) found 277 unbalanced copy number variations, including deletions, duplications, translocations, and inversions, in 189 $(44 \%)$ of 427 families with autism spectrum disorder. These specific changes were not present in a total of about 1,600 controls, although control individuals also carried many $\mathrm{CNV}$. Although most variants were inherited among the patients, 27 cases had de novo alterations, and $3(11 \%)$ of these individuals had 2 or more changes.

In the most recent years (see table 3) the using of array CGH in large cohorts enabled us to uncover new candidate-genes for autism with high statistical power. Most of them are responsible for normal functioning of nervous system.

\begin{tabular}{|l|l|l|l|l|}
\hline Chr & Cytoband & $\begin{array}{l}\text { Candidate- } \\
\text { genes }\end{array}$ & Function & References \\
\hline $\mathbf{1}$ & $\mathbf{1 q 2 1}$ & HYDIN & hydrocephalus inducing & $\begin{array}{l}\text { Itsara } \\
\text { et al. (2009) }\end{array}$ \\
\hline $\mathbf{2}$ & $\mathbf{2 p 1 6}$ & NRXN1 & neuronal cell adhesion & $\begin{array}{l}\text { Rujescu } \\
\text { et al. (2009) }\end{array}$ \\
\hline $\mathbf{3}$ & $\mathbf{3 q 2 9}$ & $\begin{array}{l}\text { FBXO45 } \\
\text { DLG1 } \\
\text { PAK2 }\end{array}$ & $\begin{array}{l}\text { synaptic transmission } \\
\text { junction formation } \\
\text { cytoskeleton } \\
\text { reorganization }\end{array}$ & $\begin{array}{l}\text { Quintero-Rivera } \\
\text { et al. (2010) }\end{array}$ \\
\hline $\begin{array}{l}\text { 3q26 } \\
\mathbf{9 q 3 3}\end{array}$ & $\begin{array}{l}\text { NLGN1 } \\
\text { ASTN2 }\end{array}$ & $\begin{array}{l}\text { neuronal network } \\
\text { formation and plasticity } \\
\text { neuronal cell surface } \\
\text { protein } \\
\text { neuronal migration }\end{array}$ & $\begin{array}{l}\text { Glessner } \\
\text { et al. (2009) }\end{array}$ \\
\hline $\mathbf{1 1}$ & $\mathbf{1 1 q 1 3}$ & SHANK2 & $\begin{array}{l}\text { molecular scaffold in the } \\
\text { postsynaptic density }\end{array}$ & $\begin{array}{l}\text { Berkel } \\
\text { et al. (2010) }\end{array}$ \\
\hline $\mathbf{1 6}$ & $\mathbf{1 6 p 1 1}$ & TBX6 & $\begin{array}{l}\text { regulation of } \\
\text { developmental processes }\end{array}$ & $\begin{array}{l}\text { Fernandez } \\
\text { et al., 2010 } \\
\text { Shinawi } \\
\text { et al. (2010) }\end{array}$ \\
\hline X & Xp22 & PTCHD1 & $\begin{array}{l}\text { patched domain } \\
\text { containing }\end{array}$ & $\begin{array}{l}\text { Whibley } \\
\text { et al. (2010) }\end{array}$ \\
\hline
\end{tabular}

Table 3. CNV in specific regions and corresponding candidate-genes for ASD

Figure 1 summarize the chromosomal locations, showing linkage with autism and containing potential candidate-genes for the disease. 

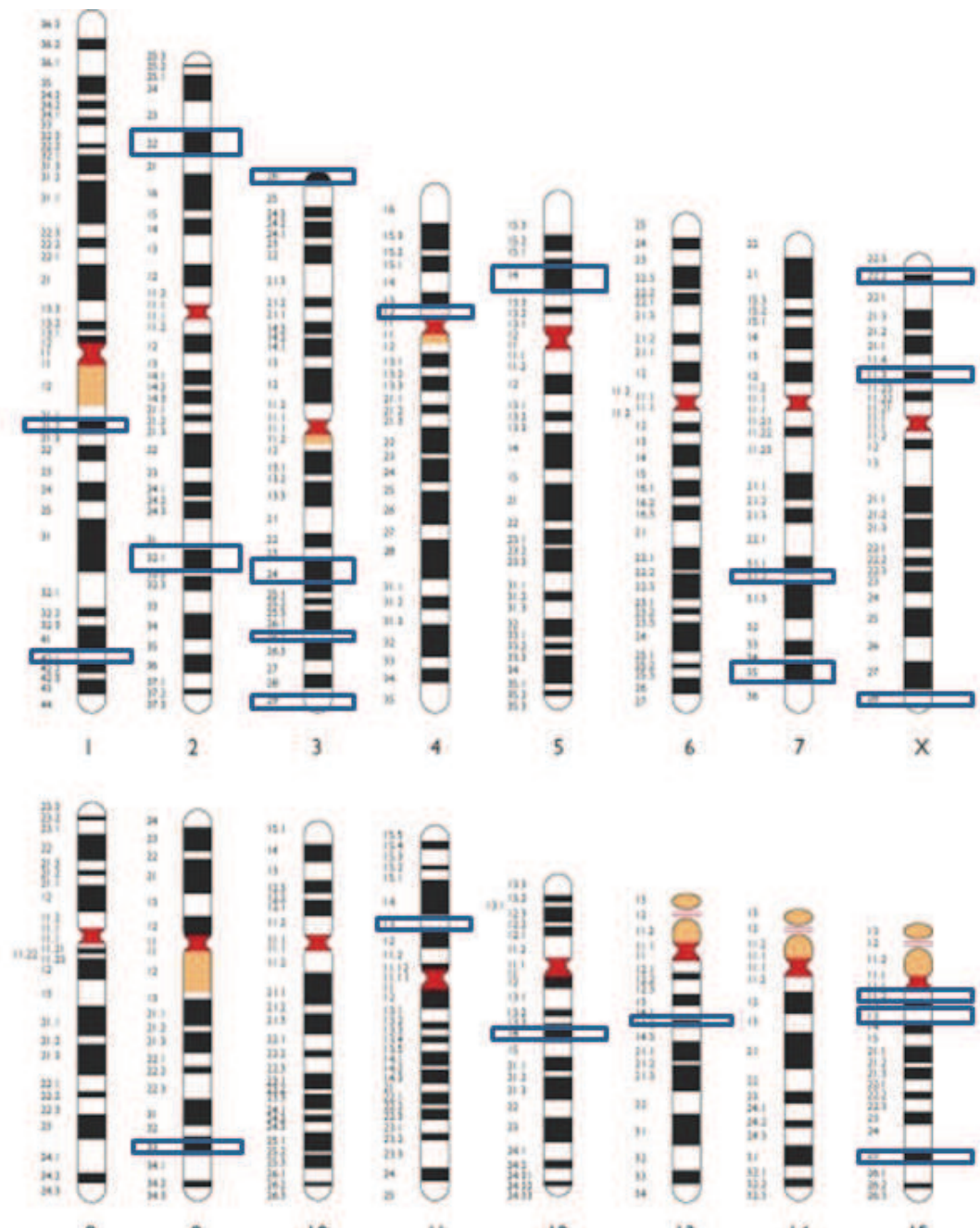

8

10

12

13

14

15

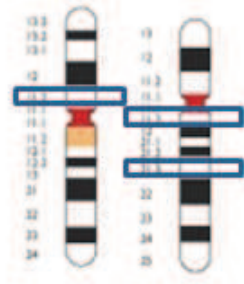

16

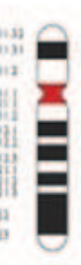

18

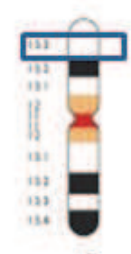

19

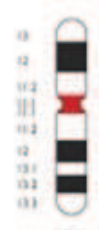

20
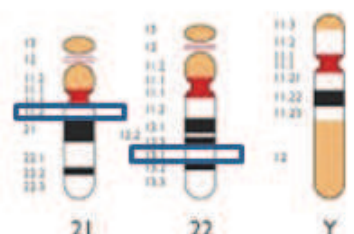

Fig. 3. Human karyogram, showing the most frequently affected chromosomes in autism and ASD. 


\section{Genetic counseling in autism}

The risk for recurrence of ASD in families having children with "idiopathic" autism is 2-8\%. The diagnosis of autism within malformative syndrome or metabolic conditions with known genetic defects could precise the risk for disease recurrence. It is recommended careful counseling in families with autistic patients when they plan future pregnancy.

In patients with autistic spectrum disorders the following genetic analyses are recommended:

- Karyotyping;

- Metabolic screening for phenylketonuria, hyper-succinyl-purinemia, lactic acidosis, abnormal metabolism of aromatic amino acids, monoamines and cholesterol, abnormal glycosylation (CDG);

- $\quad$ Screening for mutations in MECP2 and FMR1 gene;

- FISH and RT-PCR for abnormalities of 15q11-13 locus (duplications, deletions and insertion);

Screening for mutations in $\mathrm{mtDNK}$;

- Comparative genomic hybridization with microarrays (arrayCGH).

The most probable multifactorial etiology of autism suggests that interactions between multiple genes cause "idiopathic" autism but that epigenetic factors and exposure to environmental modifiers may contribute to variable expressions of autism-related traits. The extensive research in this area, consolidating clinical, genetic, metabolic and environmental data will contribute to better understanding of the disease and to better clinical management.

\section{References}

[1] Avdjieva D., Toncheva D. Genetics of Autistic Spectrum Disorders. In: “Medical Genetics in Postgenomic era", 1st edition 2010

[2] Abramson, R. K., Wright, H. H., Carpenter, R., Brennan, W., Lumpuy, O., Cole, E., Young, S. R. Elevated blood serotonin in autistic probands and their first-degree relatives. J. Autism Dev. Disord. 19: 397-407, 1989.

[3] Alarcon, M., Abrahams, B. S., Stone, J. L., Duvall, J. A., Perederiy, J. V., Bomar, J. M., Sebat, J., Wigler, M., Martin, C. L., Ledbetter, D. H., Nelson, S. F., Cantor, R. M., Geschwind, D. H. Linkage, association, and gene-expression analyses identify CNTNAP2 as an autism-susceptibility gene. Am. J. Hum. Genet. 82: 150-159, 2008.

[4] Arking, D. E., Cutler, D. J., Brune, C. W., Teslovich, T. M., West, K., Ikeda, M., Rea, A., Guy, M., Lin, S., Cook, E. H., Jr., Chakravarti, A. A common genetic variant in the neurexin superfamily member CNTNAP2 increases familial risk of autism. Am. J. Hum. Genet. 82: 160-164, 2008.

[5] Auranen, M., Vanhala, R., Varilo, T., Ayers, K., Kempas, E., Ylisaukko-oja, T., Sinsheimer, J. S., Peltonen, L., Jarvela, I. A genomewide screen for autism-spectrum disorders: evidence for a major susceptibility locus on chromosome 3q25-27. Am. J. Hum. Genet. 71: 777-790, 2002.

[6] Bacchelli, E., Blasi, F., Biondolillo, M., Lamb, J. A., Bonora, E., Barnby, G., Parr, J., Beyer, K. S., Klauck, S. M., Poustka, A., Bailey, A. J., Monaco, A. P., Maestrini, E., 
International Molecular Genetic Study of Autism Consortium (IMGSAC). Screening of nine candidate genes for autism on chromosome $2 \mathrm{q}$ reveals rare nonsynonymous variants in the cAMP-GEFII gene. Molec. Psychiat. 8: 916-924, 2003.

[7] Bakkaloglu, B., O'Roak, B. J., Louvi, A., Gupta, A. R., Abelson, J. F., Morgan, T. M., Chawarska, K., Klin, A., Ercan-Sencicek, A. G., Stillman, A. A., Tanriover, G., Abrahams, B. S., Duvall, J. A., Robbins, E. M., Geschwind, D. H., Biederer, T., Gunel, M., Lifton, R. P., State, M. W. Molecular cytogenetic analysis and resequencing of contactin associated protein-like 2 in autism spectrum disorders. Am. J. Hum. Genet. 82: 165-173, 2008.

[8] Bartlett, C. W., Goedken, R., Vieland, V. J. Effects of updating linkage evidence across subsets of data: reanalysis of the Autism Genetic Resource Exchange data set. Am. J. Hum. Genet. 76: 688-695, 2005.

[9] Benayed, R., Gharani, N., Rossman, I., Mancuso, V., Lazar, G., Kamdar, S., Bruse, S. E., Tischfield, S., Smith, B. J., Zimmerman, R. A., DiCicco-Bloom, E., Brzustowicz, L. M., Millonig, J. H. Support for the homeobox transcription factor gene engrailed 2 as an autism spectrum disorder susceptibility locus. Am. J. Hum. Genet. 77: 851868, 2005.

[10] Berkel, S., Marshall, C. R., Weiss, B., Howe, J., Roeth, R., Moog, U., Endris, V., Roberts, W., Szatmari, P., Pinto, D., Bonin, M., Riess, A., Engels, H., Sprengel, R., Scherer, S. W., Rappold, G. A. Mutations in the SHANK2 synaptic scaffolding gene in autism spectrum disorder and mental retardation. Nature Genet. 42: 489-491, 2010.

[11] Bijlsma, E. K., Gijsbers, A. C. J., Schuurs-Hoeijmakers, J. H. M., van Haeringen, A., Fransen van de Putte, D. E., Anderlid, B.-M., Lundin, J., Lapunzina, P., Perez Jurado, L. A., Delle Chiaie, B., Loeys, B., Menten, B., and 13 others. Extending the phenotype of recurrent rearrangements of $16 \mathrm{p} 11.2$ : deletions in mentally retarded patients without autism and in normal individuals. Europ. J. Med. Genet. 52: 77-87, 2009.

[12] Bonati, M. T., Finelli, P., Giardino, D., Gottardi, G., Roberts, W., Larizza, L. Trisomy 15q25.2-qter in an autistic child: genotype-phenotype correlations. Am. J. Med. Genet. 133A: 184-188, 2005.

[13] Buxbaum, J. D., Silverman, J., Keddache, M., Smith, C. J., Hollander, E., Ramoz, N., Reichert, J. G. Linkage analysis for autism in a subset families with obsessivecompulsive behaviors: evidence for an autism susceptibility gene on chromosome 1 and further support for susceptibility genes on chromosomes 6 and 19. Molec. Psychiat. 9: 144-150, 2004.

[14] Campbell, D. B., Sutcliffe, J. S., Ebert, P. J., Militerni, R., Bravaccio, C., Trillo, S., Elia, M., Schneider, C., Melmed, R., Sacco, R., Persico, A. M., Levitt, P. A genetic variant that disrupts MET transcription is associated with autism. Proc. Nat. Acad. Sci. 103: 16834-16839, 2006.

[15] Cantor, R. M., Kono, N., Duvall, J. A., Alvarez-Retuerto, A., Stone, J. L., Alarcon, M., Nelson, S. F., Geschwind, D. H. Replication of autism linkage: fine-mapping peak at 17q21. Am. J. Hum. Genet. 76: 1050-1056, 2005.

[16] Carney, R. M., Wolpert, C. M., Ravan, S. A., Shahbazian, M., Ashley-Koch, A., Cuccaro, M. L., Vance, J. M., Pericak-Vance, M. A. Identification of MeCP2 mutations in a series of females with autistic disorder. Pediat. Neurol. 28: 205-211, 2003. 
[17] Carter NP (2007). Methods and strategies for analyzing copy number variation using DNA microarrrays. Nat. Genet. 39: 16-21.

[18] Chiocchetti, A., Pakalapati, G., Duketis, E., Wiemann, S., Poustka, A., Poustka, F., Klauck, S. M. Mutation and expression analyses of the ribosomal protein gene RPL10 is an extended German sample of patients with autism spectrum disorder. Am. J. Med. Genet. 155A: 1472-1475, 2011.

[19] Cohen, I. L., Liu, X., Lewis, M. E., Chudley, A., Forster-Gibson, C., Gonzalez, M., Jenkins, E. C., Brown, W. T., Holden, J. J. A. Autism severity is associated with child and maternal MAOA genotypes. Clin. Genet. 79: 355-362, 2011.

[20] Collins, A. L., Ma, D., Whitehead, P. L., Martin, E. R., Wright, H. H., Abramson, R. K., Hussman, J. P., Haines, J. L., Cuccaro, M. L., Gilbert, J. R., Pericak-Vance, M. A. Investigation of autism and GABA receptor subunit genes in multiple ethnic groups. Neurogenetics 7: 167-174, 2006.

[21] Conroy, J., Meally, E., Kearney, G., Fitzgerald, M., Gill, M., Gallagher, L. Serotonin transporter gene and autism: a haplotype analysis in an Irish autistic population. Molec. Psychiat. 9: 587-593, 2004.

[22] Cook, E. H., Jr., Lindgren, V., Leventhal, B. L., Courchesne, R., Lincoln, A., Shulman, C., Lord, C., Courchesne, E. Autism or atypical autism in maternally but not paternally derived proximal 15q duplication. Am. J. Hum. Genet. 60: 928-934, 1997.

[23] de Silva, M. G., Elliott, K., Dahl, H.-H., Fitzpatrick, E., Wilcox, S., Delatycki, M., Williamson, R., Efron, D., Lynch, M., Forrest, S. Disruption of a novel member of a sodium/hydrogen exchanger family and DOCK3 is associated with an attention deficit hyperactivity disorder-like phenotype. J. Med. Genet. 40: 733-740, 2003.

[24] Depienne, C., Heron, D., Betancur, C., Benyahia, B., Trouillard, O., Bouteiller, D., Verloes, A., LeGuern, E., Leboyer, M., Brice, A. Autism, language delay and mental retardation in a patient with 7q11 duplication. (Letter) J. Med. Genet. 44: 452-458, 2007.

[25] Eichler, E. E., Zimmerman, A. W. A hot spot of genetic instability in autism. (Editorial) New Eng. J. Med. 358: 737-739, 2008.

[26] Fernandez, B. A., Roberts, W., Chung, B., Weksberg, R., Meyn, S., Szatmari, P., JosephGeorge, A. M., MacKay, S., Whitten, K., Noble, B., Vardy, C., Crosbie, V., Luscombe, S., Tucker, E., Turner, L., Marshall, C. R., Scherer, S. W. Phenotypic spectrum associated with de novo and inherited deletions and duplications at 16 p11.2 in individuals ascertained for diagnosis of autism spectrum disorder. J. Med. Genet. 47: 195-203, 2010.

[27] Fernandez, B. A., Roberts, W., Chung, B., Weksberg, R., Meyn, S., Szatmari, P., JosephGeorge, A. M., MacKay, S., Whitten, K., Noble, B., Vardy, C., Crosbie, V., Luscombe, S., Tucker, E., Turner, L., Marshall, C. R., Scherer, S. W. Phenotypic spectrum associated with de novo and inherited deletions and duplications at 16 p11.2 in individuals ascertained for diagnosis of autism spectrum disorder. J. Med. Genet. 47: 195-203, 2010.

[28] Filges, I., Rothlisberger, B., Blattner, A., Boesch, N., Demougin, P., Wenzel, F., Huber, A. R., Heinimann, K., Weber, P., Miny, P. Deletion in Xp22.11: PTCHD1 is a candidate gene for X-linked intellectual disability with or without autism. Clin. Genet. 79: 7985, 2011. 
[29] Folstein, S. E., Mankoski, R. E. Chromosome 7q: where autism meets language disorder? (Editorial) Am. J. Hum. Genet. 67: 278-281, 2000.

[30] Freeman JL, Perry GH, Feuk L, Redon R, McCarroll SA, Altshuler DM, Aburatani H, Jones KW, Tyler-Smith C, Hurles MEl (2006). Copy number variation: new insights in genome diversity. Genome Res. 16: 949-961.

[31] Gharani, N., Benayed, R., Mancuso, V., Brzustowicz, L. M., Millonig, J. H. Association of the homeobox transcription factor, engrailed 2, 3, with autism spectrum disorder. Molec. Psychiat. 9: 474-484, 2004.

[32] Glessner, J. T., Wang, K., Cai, G., Korvatska, O., Kim, C. E., Wood, S., Zhang, H., Estes, A., Brune, C. W., Bradfield, J. P., Imielinski, M., Frackelton, E. C., and 47 others. Autism genome-wide copy number variation reveals ubiquitin and neuronal genes. Nature 459: 569-573, 2009.

[33] Gong, X., Delorme, R., Fauchereau, F., Durand, C. M., Chaste, P., Betancur, C., GoubranBotros, H., Nygren, G., Anckarsater, H., Rastam, M., Gillberg, I. C., Kopp, S., Mouren-Simeoni, M.-C., Gillberg, C., Leboyer, M., Bourgeron, T. An investigation of ribosomal protein L10 gene in autism spectrum disorders. BioMed Med. Genet. 10: , 2009.

[34] Itsara, A., Cooper, G. M., Baker, C., Girirajan, S., Li, J., Absher, D., Krauss, R. M., Myers, R. M., Ridker, P. M., Chasman, D. I., Mefford, H., Ying, P., Nickerson, D. A., Eichler, E. E. Population analysis of large copy number variants and hotspots of human genetic disease. Am. J. Hum. Genet. 84: 148-161, 2009.

[35] Kilpinen, H., Ylisaukko-oja, T., Rehnstrom, K., Gaal, E., Turunen, J. A., Kempas, E., von Wendt, L., Varilo, T., Peltonen, L. Linkage and linkage disequilibrium scan for autism loci in an extended pedigree from Finland. Hum. Molec. Genet. 18: 29122921, 2009.

[36] Kim, S. J., Cox, N., Courchesne, R., Lord, C., Corsello, C., Akshoomoff, N., Guter, S., Leventhal, B. L., Courchesne, E., Cook, E. H., Jr. Transmission disequilibrium mapping at the serotonin transporter gene (SLC6A4) region in autistic disorder. Molec. Psychiat. 7: 278-288, 2002.

[37] Klauck, S. M., Poustka, F., Benner, A., Lesch, K.-P., Poustka, A. Serotonin transporter (5HTT) gene variants associated with autism? Hum. Molec. Genet. 6: 2233-2238, 1997.

[38] Lamb, J. A., Barnby, G., Bonora, E., Sykes, N., Bacchelli, E., Blasi, F., Maestrini, E., Broxholme, J., Tzenova, J., Weeks, D., Bailey, A. J., Monaco, A. P., International Molecular Genetic Study of Autism Consortium. Analysis of IMGSAC autism susceptibility loci: evidence for sex limited and parent of origin specific effects. J. Med. Genet. 42: 132-137, 2005.

[39] Lindquist, S. G., Kirchhoff, M., Lundsteen, C., Pedersen, W., Erichsen, G., Kristensen, K., Lillquist, K., Smedegaard, H. H., Skov, L., Tommerup, N., Brondum-Nielsen, K. Further delineation of the 22q13 deletion syndrome. Clin. Dysmorph. 14: 55-60, 2005.

[40] Liu, X., Novosedlik, N., Wang, A., Hudson, M. L., Cohen, I. L., Chudley, A. E., ForsterGibson, C. J., Lewis, S. M. E., Holden, J. J. A. The DLX1 and DLX2 genes and susceptibility to autism spectrum disorders. Europ. J. Hum. Genet. 17: 228-235, 2009

[41] Luciani, J. J., de Mas, P., Depetris, D., Mignon-Ravix, C., Bottani, A., Prieur, M., Jonveaux, P., Philippe, A., Bourrouillou, G., de Martinville, B., Delobel, B., Vallee, L., Croquette, M.-F., Mattei, M.-G. Telomeric 22q13 deletions resulting from rings, 
simple deletions, and translocations: cytogenetic, molecular, and clinical analyses of 32 new observations. J. Med. Genet. 40: 690-696, 2003.

[42] Ma, D. Q., Cuccaro, M. L., Jaworski, J. M., Haynes, C. S., Stephan, D. A., Parod, J., Abramson, R. K., Wright, H. H., Gilbert, J. R., Haines, J. L., Pericak-Vance, M. A. Dissecting the locus heterogeneity of autism: significant linkage to chromosome 12q14. Molec. Psychiat. 12: 376-384, 2007.

[43] Ma, D. Q., Whitehead, P. L., Menold, M. M., Martin, E. R., Ashley-Koch, A. E., Mei, H., Ritchie, M. D., DeLong, G. R., Abramson, R. K., Wright, H. H., Cuccaro, M. L., Hussman, J. P., Gilbert, J. R., Pericak-Vance, M. A. Identification of significant association and gene-gene interaction of GABA receptor subunit genes in autism. Am. J. Hum. Genet. 77: 377-388, 2005.

[44] Ma, D., Salyakina, D., Jaworski, J. M., Konidari, I., Whitehead, P. L., Andersen, A. N., Hoffman, J. D., Slifer, S. H., Hedges, D. J., Cukier, H. N., Griswold, A. J., McCauley, J. L., and 9 others. A genome-wide association study of autism reveals a common novel risk locus at 5p14.1. Ann. Hum. Genet. 73: 263-273, 2009.

[45] Marshall, C. R., Noor, A., Vincent, J. B., Lionel, A. C., Feuk, L., Skaug, J., Shago, M., Moessner, R., Pinto, D., Ren, Y., Thiruvahindrapduram, B., Fiebig, A., and 23 others. Structural variation of chromosomes in autism spectrum disorder. Am. J. Hum. Genet. 82: 477-488, 2008.

[46] Maussion, G., Carayol, J., Lepagnol-Bestel, A.-M., Tores, F., Loe-Mie, Y., Milbreta, U., Rousseau, F., Fontaine, K., Renaud, J., Moalic, J.-M., Philippi, A., Chedotal, A., Gorwood, P., Ramoz, N., Hager, J., Simonneau, M. Convergent evidence identifying $\mathrm{MAP} /$ microtubule affinity-regulating kinase 1 (MARK1) as a susceptibility gene for autism. Hum. Molec. Genet. 17: 2541-2551, 2008.

[47] McCarroll SA, Altshuler DM (2007). Copy-number variation and association studies of human disease. Nat. Genet. 39: 37-42.

[48] Molloy, C. A., Keddache, M., Martin, L. J. Evidence for linkage on 21q and 7q in a subset of autism characterized by developmental regression. Molec. Psychiat. 10: 741-746, 2005.

[49] Morrow, E. M., Yoo, S.-Y., Flavell, S. W., Kim, T.-K., Lin, Y., Hill, R. S., Mukaddes, N. M., Balkhy, S., Gascon, G., Hashmi, A., Al-Saad, S., Ware, J., and 13 others. Identifying autism loci and genes by tracing recent shared ancestry. Science 321: 218-223, 2008.

[50] Napolioni, V., Lombardi, F., Sacco, R., Curatolo, P., Manzi, B., Alessandrelli, R., Militerni, R., Bravaccio, C., Lenti, C., Saccani, M., Schneider, C., Melmed, R., Pascucci, T., Puglisi-Allegra, S., Reichelt, K.-L., Rousseau, F., Lewin, P., Persico, A. M. Family-based association study of ITGB3 in autism spectrum disorder and its endophenotypes. Europ. J. Hum. Genet. 19: 353-359, 2011.

[51] Newbury, D. F., Warburton, P. C., Wilson, N., Bacchelli, E., Carone, S., International Molecular Genetic Study of Autism Consortium, Lamb, J. A., Maestrini, E., Volpi, E. V., Mohammed, S., Baird, G., Monaco, A. P. Mapping of partially overlapping de novo deletions across an autism susceptibility region (AUTS5) in two unrelated individuals affected by developmental delays with communication impairment. Am. J. Med. Genet. 149A: 588-597, 2009. 
[52] Piven, J., Tsai, G. C., Nehme, E., Coyle, J. T., Chase, G. A., Folstein, S. E. Platelet serotonin, a possible marker for familial autism. J. Autism Dev. Disord. 21: 51-59, 1991.

[53] Quintero-Rivera, F., Sharifi-Hannauer, P., Martinez-Agosto, J. A. Autistic and psychiatric findings associated with the 3q29 microdeletion syndrome: case report and review. Am. J. Med. Genet. 152A: 2459-2467, 2010.

[54] Ramoz, N., Reichert, J. G., Smith, C. J., Silverman, J. M., Bespalova, I. N., Davis, K. L., Buxbaum, J. D. Linkage and association of the mitochondrial aspartate/glutamate carrier SLC25A12 gene with autism. Am. J. Psychiat. 161: 662-669, 2004.

[55] Redon R, Ishikawa S, Fitch KR, Feuk L, Perry GH, Andrews TD, Fiegler H, Shapero $\mathrm{MH}$, Carson AR, Chen $\mathrm{W}$ et al (2006). Global variation in copy number in the human genome. Nature 444: 444-454.

[56] Rujescu, D., Ingason, A., Cichon, S., Pietilainen, O. P. H., Barnes, M. R., Toulopoulou, T., Picchioni, M., Vassos, E., Ettinger, U., Bramon, E., Murray, R., Ruggeri, M., and 41 others. Disruption of the neurexin 1 gene is associated with schizophrenia. Hum. Molec. Genet. 18: 988-996, 2009.

[57] Sebat, J., Lakshmi, B., Malhotra, D., Troge, J., Lese-Martin, C., Walsh, T., Yamrom, B., Yoon, S., Krasnitz, A., Kendall, J., Leotta, A., Pai, D., and 20 others. Strong association of de novo copy number mutations with autism. Science 316: 445-449, 2007.

[58] Segurado, R., Conroy, J., Meally, E., Fitzgerald, M., Gill, M., Gallagher, L. Confirmation of association between autism and the mitochondrial aspartate/glutamate carrier SLC25A12 gene on chromosome 2q31. Am. J. Psychiat. 162: 2182-2184, 2005.

[59] Shao, Y., Cuccaro, M. L., Hauser, E. R., Raiford, K. L., Menold, M. M., Wolpert, C. M., Ravan, S. A., Elston, L., Decena, K., Donnelly, S. L., Abramson, R. K., Wright, H. H., DeLong, G. R., Gilbert, J. R., Pericak-Vance, M. A. Fine mapping of autistic disorder to chromosome 15q11-q13 by use of phenotypic subtypes. Am. J. Hum. Genet. 72: 539-548, 2003.

[60] Shinawi, M., Liu, P., Kang, S.-H. L., Shen, J., Belmont, J. W., Scott, D. A., Probst, F. J., Craigen, W. J., Graham, B. H., Pursley, A., Clark, G., Lee, J., and 16 others. Recurrent reciprocal 16p11.2 rearrangements associated with global developmental delay, behavioural problems, dysmorphism, epilepsy, and abnormal head size. J. Med. Genet. 47: 332-341, 2010

[61] Somerville, M. J., Mervis, C. B., Young, E. J., Seo, E.-J., del Campo, M., Bamforth, S., Peregrine, E., Loo, W., Lilley, M., Perez-Jurado, L. A., Morris, C. A., Scherer, S. W., Osborne, L. R. Severe expressive-language delay related to duplication of the Williams-Beuren locus. New Eng. J. Med. 353: 1694-1701, 2005.

[62] Steele, M. M., Al-Adeimi, M., Siu, V. M., Fan, Y.-S. Brief report: a case of autism with interstitial deletion of chromosome 13. J. Autism Dev. Disord. 31: 231-234, 2001.

[63] Tentler, D., Johannesson, T., Johansson, M., Rastam, M., Gillberg, C., Orsmark, C., Carlsson, B., Wahlstrom, J., Dahl, N. A candidate region for Asperger syndrome defined by two 17p breakpoints. Europ. J. Hum. Genet. 11: 189-195, 2002.

[64] Tochigi, M., Kato, C., Koishi, S., Kawakubo, Y., Yamamoto, K., Matsumoto, H., Hashimoto, O., Kim, S.-Y., Watanabe, K., Kano, Y., Nanba, E., Kato, N., Sasaki, T. No evidence for significant association between GABA receptor genes in 
chromosome 15q11-q13 and autism in a Japanese population. J. Hum. Genet. 52: 985-989, 2007.

[65] Vernes, S. C., Newbury, D. F., Abrahams, B. S., Winchester, L., Nicod, J., Groszer, M., Alarcon, M., Oliver, P. L., Davies, K. E., Geschwind, D. H., Monaco, A. P., Fisher, S. E. A functional genetic link between distinct developmental language disorders. New Eng. J. Med. 359: 2337-2345, 2008.

[66] Vincent, J. B., Herbrick, J.-A., Gurling, H. M. D., Bolton, P. F., Roberts, W., Scherer, S. W. Identification of a novel gene on chromosome $7 \mathrm{q} 31$ that is interrupted by a translocation breakpoint in an autistic individual. Am. J. Hum. Genet. 67: 510-514, 2000.

[67] Wang, K., Zhang, H., Ma, D., Bucan, M., Glessner, J. T., Abrahams, B. S., Salyakina, D., Imielinski, M., Bradfield, J. P., Sleiman, P. M. A., Kim, C. E., Hou, C., and 44 others. Common genetic variants on 5 p14.1 associate with autism spectrum disorders. Nature 459: 528-533, 2009.

[68] Wassink, T. H., Piven, J., Vieland, V. J., Huang, J., Swiderski, R. E., Pietila, J., Braun, T., Beck, G., Folstein, S. E., Haines, J. L., Sheffield, V. C. Evidence supporting WNT2 as an autism susceptibility gene. Am. J. Med. Genet. 105: 406-413, 2001.

[69] Weiss, L. A., Kosova, G., Delahanty, R. J., Jiang, L., Cook, E. H., Jr., Ober, C., Sutcliffe, J. S. Variation in ITGB3 is associated with whole-blood serotonin level and autism susceptibility. Europ. J. Hum. Genet. 14: 923-931, 2006.

[70] Whibley, A. C., Plagnol, V., Tarpey, P. S., Abidi, F., Fullston, T., Choma, M. K., Boucher, C. A., Shepherd, L., Willatt, L., Parkin, G., Smith, R., Futreal, P. A., and 12 others. Fine-scale survey of $\mathrm{X}$ chromosome copy number variants and indels underlying intellectual disability. Am. J. Hum. Genet. 87: 173-188, 2010.

[71] Wilson, H. L., Crolla, J. A., Walker, D., Artifoni, L., Dallapiccola, B., Takano, T., Vasudevan, P., Huang, S., Maloney, V., Yobb, T., Quarrell, O., McDermid, H. E. Interstitial 22q13 deletions: genes other than SHANK3 have major effects on cognitive and language development. Europ. J. Hum. Genet. 16: 1301-1310, 2008.

[72] Wilson, H. L., Wong, A. C. C., Shaw, S. R., Tse, W.-Y., Stapleton, G. A., Phelan, M. C., $\mathrm{Hu}$, S., Marshall, J., McDermid, H. E. Molecular characterisation of the 22q13 deletion syndrome supports the role of haploinsufficiency of SHANK3/PROSAP2 in the major neurological symptoms. J. Med. Genet. 40: 575-584, 2003.

[73] Wolpert, C. M., Menold, M. M., Bass, M. P., Qumsiyeh, M. B., Donnelly, S. L., Ravan, S. A., Vance, J. M., Gilbert, J. R., Abramson, R. K., Wright, H. H., Cuccaro, M. L., Pericak-Vance, M. A. Three probands with autistic disorder and isodicentric chromosome 15. Am. J. Med. Genet. (Neuropsychiat. Genet.) 96: 365-372, 2000. 


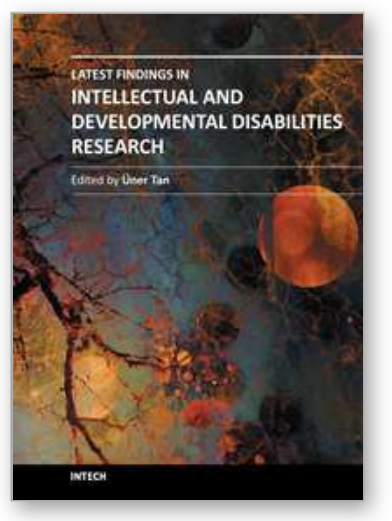

\author{
Latest Findings in Intellectual and Developmental Disabilities \\ Research \\ Edited by Prof. Uner Tan
}

ISBN 978-953-307-865-6

Hard cover, 404 pages

Publisher InTech

Published online 15, February, 2012

Published in print edition February, 2012

Intellectual and Developmental Disabilities presents reports on a wide range of areas in the field of neurological and intellectual disability, including habitual human quadrupedal locomotion with associated cognitive disabilities, Fragile $X$ syndrome, autism spectrum disorders, Down syndrome, and intellectual developmental disability among children in an African setting. Studies are presented from researchers around the world, looking at aspects as wide-ranging as the genetics behind the conditions to new and innovative therapeutic approaches.

\title{
How to reference
}

In order to correctly reference this scholarly work, feel free to copy and paste the following:

Ivanka Dimova and Draga Toncheva (2012). Genetic Aspects of Autism Spectrum Disorders: From Bench to Bedside, Latest Findings in Intellectual and Developmental Disabilities Research, Prof. Uner Tan (Ed.), ISBN: 978-953-307-865-6, InTech, Available from: http://www.intechopen.com/books/latest-findings-in-intellectualand-developmental-disabilities-research/genetic-aspects-of-autism-spectrum-disorders-from-bench-to-bedside

\section{INTECH}

open science | open minds

\section{InTech Europe}

University Campus STeP Ri

Slavka Krautzeka 83/A

51000 Rijeka, Croatia

Phone: +385 (51) 770447

Fax: +385 (51) 686166

www.intechopen.com

\section{InTech China}

Unit 405, Office Block, Hotel Equatorial Shanghai

No.65, Yan An Road (West), Shanghai, 200040, China

中国上海市延安西路65号上海国际贵都大饭店办公楼 405 单元

Phone: +86-21-62489820

Fax: +86-21-62489821 
(C) 2012 The Author(s). Licensee IntechOpen. This is an open access article distributed under the terms of the Creative Commons Attribution 3.0 License, which permits unrestricted use, distribution, and reproduction in any medium, provided the original work is properly cited. 